\title{
A Case of Laryngeal Mucosa Associated Lymphoid Tissue Lymphoma Mimicking Laryngeal Amyloidosis
}

\author{
Min Woo Kim, Min Young Kwak, Jun Yong Choi, and Dong Sik Chang ${ }^{(D)}$ \\ Department of Otolaryngology-Head and Neck Surgery, Eulji University Medical Center, Eulji University School of Medicine, \\ Daejeon, Korea \\ 아밀로이드증으로 오인된 후두에 발생한 점막 연관 림프조직 림프종 1예 \\ 김민우 · 곽민영 · 최준용 · 장동식 \\ 을지대학교 의과대학 이비인후과학교실
}

\author{
Received October 13, 2020 \\ Revised December 3, 2020 \\ Accepted December 22, 2020 \\ Address for correspondence \\ Dong Sik Chang, MD \\ Department of Otolaryngology- \\ Head and Neck Surgery, \\ Eulji University Medical Center, \\ Eulji University School of Medicine, \\ 95 Dunsanse-ro, Seo-gu, \\ Daejeon 32233, Korea \\ Tel $+82-42-611-3129$ \\ Fax $+82-42-611-3136$ \\ E-mail erotica@eulji.ac.kr
}

Laryngeal amyloidosis is a rare disorder characterized by localized amyloid deposition and carries an excellent prognosis. On the other hand, mucosa associated lymphoid tissue (MALT) lymphoma is the most common type of marginal zone lymphoma. MALT lymphoma has a poorer prognosis compared to laryngeal amyloidosis due to more frequent local recurrence, distant metastasis and malignant changes. Despite the differences, as both are found in the form of benign mass and have slow progression, accurate diagnosis is necessary. This report deals with the case of a patient with voice change accompanied by a mass, in which the initial biopsy did not include enough specimen for an accurate diagnosis. However, in the second attempt, an adequate sample was obtained, hence the final diagnosis of laryngeal MALT lymphoma. Based on our recent experience and a review of related literature, we report a case of laryngeal MALT lymphoma mimicking laryngeal amyloidosis.

Korean J Otorhinolaryngol-Head Neck Surg 2021;64(9):669-73

Keywords Amyloidosis; Laryngeal cancer; Mucosa associated lymphoid tissue lymphoma.

\section{서 론}

후두의 아밀로이드증은 부정형 단백양 물질이 후두에 국소 적으로 침착되어 발생하는 비교적 드문 질환으로, 예후가 양 호한 질환으로 알려져 있다. 서서히 진행하는 경향이 있으며, 주로 환자는 음성변화, 기침, 호흡곤란 등의 증상을 주소로 내원하게 된다. ${ }^{1}$ 반면에, 점막 연관성 림프조직(mucosa associated lymphoid tissue, MALT) 림프종은 변연부 림프종 중 가장 흔하게 발생하는 종류로, 주로 림프절 외의 점막 연관 성 림프조직에서 발생하는 것으로 알려져 있다.2) 아밀로이드 증과 MALT 림프종은 모두 진행이 더디며 양성 종괴의 형태

This is an Open Access article distributed under the terms of the Creative Commons Attribution Non-Commercial License (https://creativecommons.org/licenses/by-nc/4.0) which permits unrestricted non-commercial use, distribution, and reproduction in any medium, provided the original work is properly cited.
로 발견되는 공통점이 있으나, MALT 림프종은 아밀로이드 증과는 다르게 국소 재발 및 원격 전이, 악성변형 가능성을 가지고 있는 특징이 있어 아밀로이드증에 비해 예후가 불량 하다. 후두에 발생한 아밀로이드증의 경우 국내외로 보고된 사례가 있으나, 현재까지 후두에 일차적으로 발생한 MALT 림프종에 대한 보고는 극히 드문 것으로 알려져 있으며, 실제 로 저자들이 조사한 국내 문헌 중 후두에 발생한 MALT 림 프종은 현재까지 보고된 바가 없었다. 이에 저자들은 초기에 아밀로이드증으로 오인된 후두의 MALT 림프종 1예를 보고 하는 바이다.

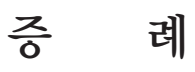

48세 남자 환자가 음성변화를 주소로 내원하였다. 증상은 
8개월 전부터 시작되었으며, 점차 악화되는 양상이라고 하였 다. 과거력 및 가족력상 특이 병력은 없었다. 후두내시경에서 우측 가성대에 경계가 불분명한 종물이 확인되었으며(Fig. 1), 성대 움직임은 이상이 없었다. 경부 조영증강 전산화단층촬영 에서 우측 혀뿌리 일부와 우측 설골주위, 양측의 후두개 및 피열후두개주름, 가성대부위를 포함하는 다발성, 소엽성 조영 증강 연조직 종물이 확인되었다(Fig. 2). 림프종 등의 악성병 변을 감별하기 위하여 경부 조영증강 자기공명영상을 촬영하 였으며, 해당 병변은 후두 아밀로이드증 등의 비종양성 병변 일 가능성이 높음이 확인되었다(Fig. 3). 우측 가성대의 연조 직 종물에 대하여 조직검사를 위한 후두미세수술을 시행하 였으며, 조직검사 결과에서 후두의 폴립 외에 특이 소견은 보 이지 않았다. 제거한 조직에서 시행한 조직 검사에서 점막하

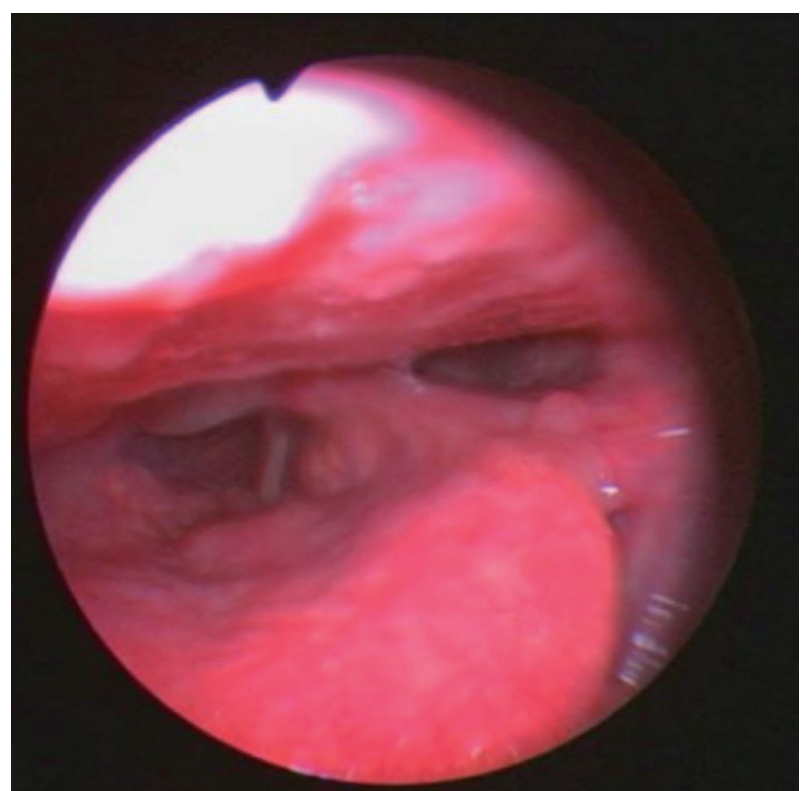

Fig. 1. Laryngoscope image that taken at initial visit. Note mass of right false vocal cord.

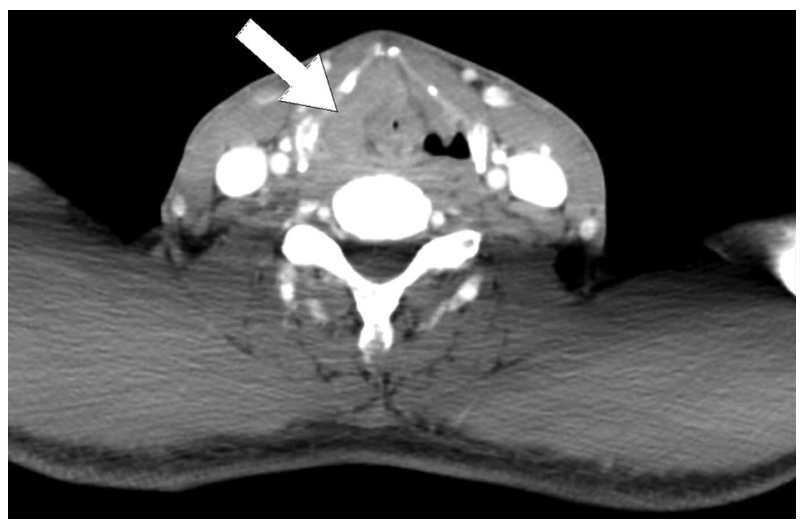

Fig. 2. Initial enhanced neck CT image of lesion. Arrow shows multifocal lobulated enhancing soft mass involving right inferior tongue base, both pre-epiglottic space, right para-hyoid, both aryepiglottic folds, false vocal cord.
병변까지 충분한 양의 조직이 확보되지 못할 가능성이 있어 경피적 총 생검(gun biopsy)을 추가로 실시하였고, 조직검사 및 면역형광염색에서 명확한 림프종 소견은 보이지 않았다. 영상학적 검사상 아밀로이드증의 가능성이 높아 그에 대한 치료를 계획하였다. 일반적으로 아밀로이드증은 외과적 제거 가 표준 치료법이나, 2/3에서 재발로 인한 재수술이 필요한 것 으로 알려져 있다. ${ }^{1)}$ 이에 따라 환자는 수술 후 음성변화가 호 전되어 정기적으로 추적 관찰하기로 하였고, 약 1 년간 증상 재발 없이 추적 관찰하였으나 이후 환자가 자의적으로 내원 을 중단하였다. 추적 관찰이 중단된지 2 년 후, 환자는 우측 경 부의 종물 및 재발한 음성변화를 주소로 본원 이비인후과로 재내원하였다. 후두내시경에서 양측 가성대 부위의 경계가 불 분명한 종물 및 그로 인한 가성대 부위의 협착이 관찰되었다 (Fig. 4). 추적 관찰을 위해 촬영한 경부 조영증강 전산화단층 촬영에서는 이전에 비해 큰 차이를 보이지 않는 다발성 소엽 성 조영증강 연조직 종물이 관찰되어 후두 아밀로이드증 등 의 비종양성 병변일 가능성이 높음이 확인되었다. 우측 경부 의 종물에 대해서는 세침흡인검사를 시행하였으며, 조직검사 결과에서 성숙한 림프세포 외에는 특이 소견은 보이지 않았 다. 이후 양측 가성대 부위의 연조직 종물에 대하여 후두미세 수술을 시행하였다. 조직검사에서 비전형적인 림프세포 침윤 이 확인되어 면역 염색을 시행하였으며, B-lymphocyte antigen CD20 (CD20), B-cell lymphoma 2 (bcl-2) 염색에서 양성을 보이고, $\mathrm{CD} 3, \mathrm{CD} 5, \mathrm{CD} 43$ 등의 염색에서 음성을 보여 점막연관 림프조직의 변연부 $\mathrm{B}-$ 세포 림프종으로 최종진단되 었다(Fig. 5), 최종 진단된 이후 병기 설정을 위해 시행한 양 전자방출단층촬영(PET-CT)에서는 우측 가성대 및 이상와, 부갑상선 주변부에 국한된 섭취 증가가 보였다. 따라서 $\mathrm{Ahn}$ Arbor 분류상 병기 IE에 해당하는 위장관 외 점막연관 림프 조직 림프종으로 진단하였으며, 후두 부위에 15회에 걸쳐 $3000 \mathrm{cGy}$ 의 방사선 치료를 시행하였다. 치료 1개월 후 시행한 경부 단층촬영에서 양측 가성대의 병변은 호전되었으며, 후두 내시경에서도 해당 병변의 소실이 확인되었고(Fig. 6), 치료 예후를 평가하기 위해 시행한 양전자방출단층촬영에서도 섭 취 증가 소견은 소실되었다. 환자는 방사선 치료 종료 후 6 개 월이 지난 현재까지 재발 및 합병증 없이 경과 관찰 중이다.

\section{고 찰}

MALT 림프종의 경우 림프절 외에 발생하는 변연부 림프 종으로, 비호지킨성 림프종 중 $\mathrm{B}$ 세포형 림프종으로 분류되 어 있다. 이러한 MALT 림프종의 경우 진행이 느리며, 다른 악성 림프종에 비교하여 예후가 좋은 특징을 보인다. 10년 

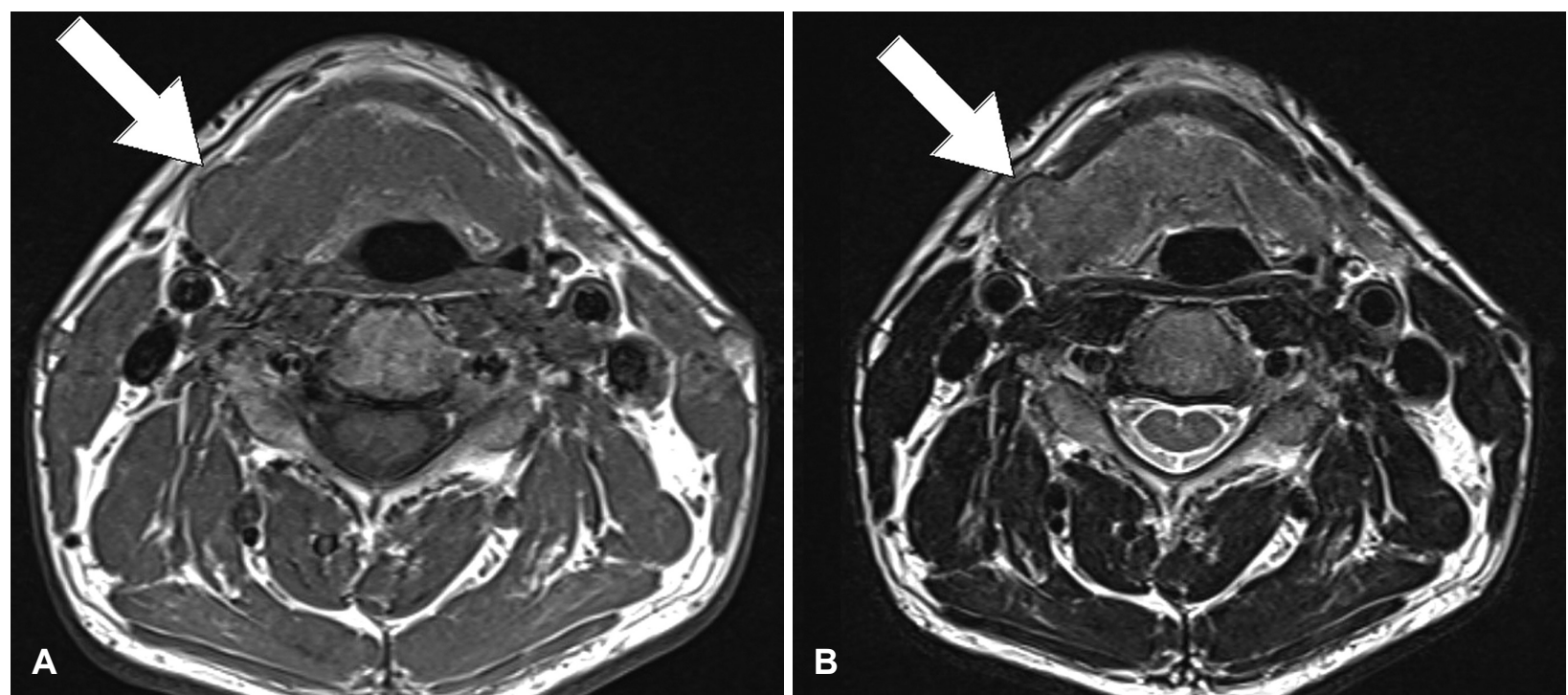

Fig. 3. Initial neck MRI images of lesion. Arrow shows multifocal lobulated soft tissue mass low signal in T1 (A), intermediate signal in T2 (B).

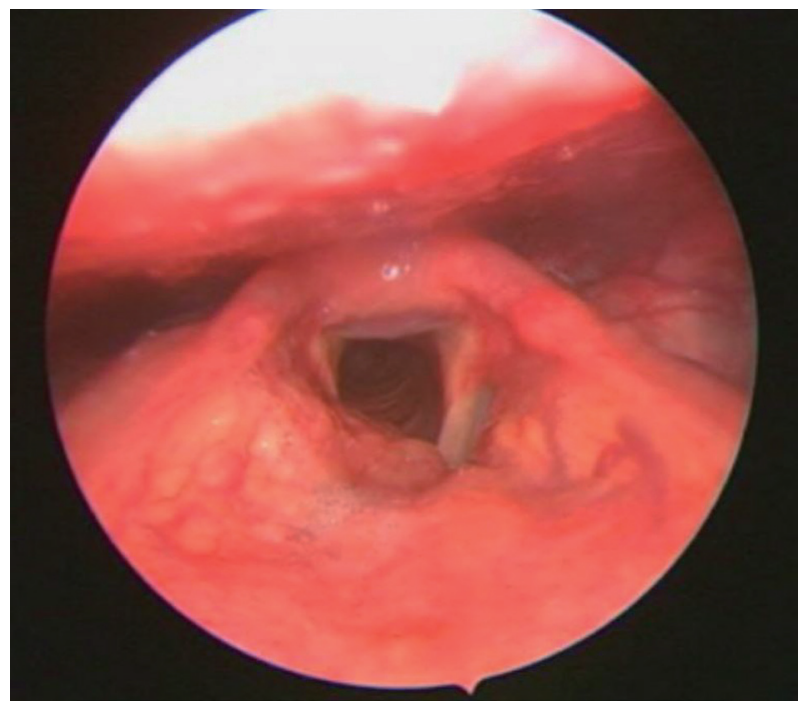

Fig. 4. Laryngoscope image that taken after recurrence. Note mass of right false vocal cord.

생존율은 79\% 87\%, 10년 무병생존율이 57\% 76\% 정도로 보고되어 있으며, 발생부 점막에 국한된 병변으로 장기간 동 안 존재하기 때문에 일반적으로 증상 발현이 느리다. ${ }^{3)} \mathrm{MALT}$ 림프종의 약 $80 \%$ 가 위장관계 점막에서 발견되며, 주로 $H$. pylori 감염에 의해 발생하는 것으로 알려져 있다. 이외에도 갑상선, 침샘, 결막, 흥선, 폐 등에도 발생되었다는 보고가 있 으며, 이러한 위장관 외의 MALT 림프종의 경우에도 위장관 에 발생한 MALT 림프종과 유사한 임상경과 및 양상을 보이 는 것으로 알려져 있다. ${ }^{4}$

MALT 림프종이 후두에 발생하는 경우는 매우 드물어 1990년 Deibold 등ㄱㅇㅣ 처음으로 보고한 이래 현재까지 세계 적으로 44예가 보고되었으며, 환자가 주로 호소한 증상은 음
성변화와 삼킴 곤란이었다. ${ }^{6}$ 후두내시경 검사를 시행했을 경 우 병변은 주로 표면이 매끈한 종괴의 형태로 보였으며, 영상 학적 검사에서도 중심부 괴사가 보이지 않는 단일 종괴로 나 타난 경우가 많았다. 이번 증례 환자의 경우 음성변화를 주 증상으로 내원하였으나, 시행한 후두 내시경 검사에서 우측 가성대의 종물이 불분명한 경계를 보였고, 영상학적 검사에서 는 단일 종괴가 아닌 다발성 연조직 종괴의 양상을 보였다.

MALT 림프종의 병태생리를 보았을 때, 위장관의 경우에 는 만성적인 H. pylori 감염으로 인한 지속적인 면역 반응으 로 발생하는 것으로 여겨지며, 위장관 외에 발생한 경우에도 만성 감염으로 인한 면역반응 혹은 자가면역반응에 의해 생 기는 것으로 알려져 있다.") Wöhrer 등 ${ }^{8}$ 의 보고에 따르면 $39 \%$ 가량의 위장관 외 장기의 MALT 림프종 환자에게서 자 가면역 질환이 동반되는 것으로 확인되었다. 따라서 이번 증 례의 환자도 자가면역 질환 동반 여부를 확인하기 위한 검사 를 시행하였으나, 자가면역 질환은 동반하고 있지 않았다.

후두에 발생한 MALT 림프종의 경우 편평세포암을 동반할 수 있고, 다른 양성 종양과 육안상 감별이 어려우며, 일반적인 조직검사만으로는 다른 염증반응과 구분하기 힘들다. 따라서 진단에는 면역조직화학적 검사를 포함한 조직검사가 필수적 이며, B-세포 표지자인 CD19, CD20, CD22, Immunoglobu$\operatorname{lin} \mathrm{M}$ (IgM), bcl-2 등의 염색에서 양성을, $\mathrm{CD} 5, \mathrm{CD} 10$, cyclin $\mathrm{D} 1, \mathrm{CD} 23$ 에서 음성을 나타내는 것으로 알려져 있다. ${ }^{9}$ 본 증 례의 환자에서는 처음 내원 시 시행한 조직 검사의 경우 점막 하층이 충분히 포함되지 않아 폴립 외에 특이 소견이 관찰되 지 않았고, 면역형광검사 시행이 불가능 하였다. 재내원 시에 는 조직을 충분히 제거 및 확보하여 정확한 조직검사가 가능 하였다. 이번 증례의 경우 앞서 보고된 후두의 MALT 림프종 

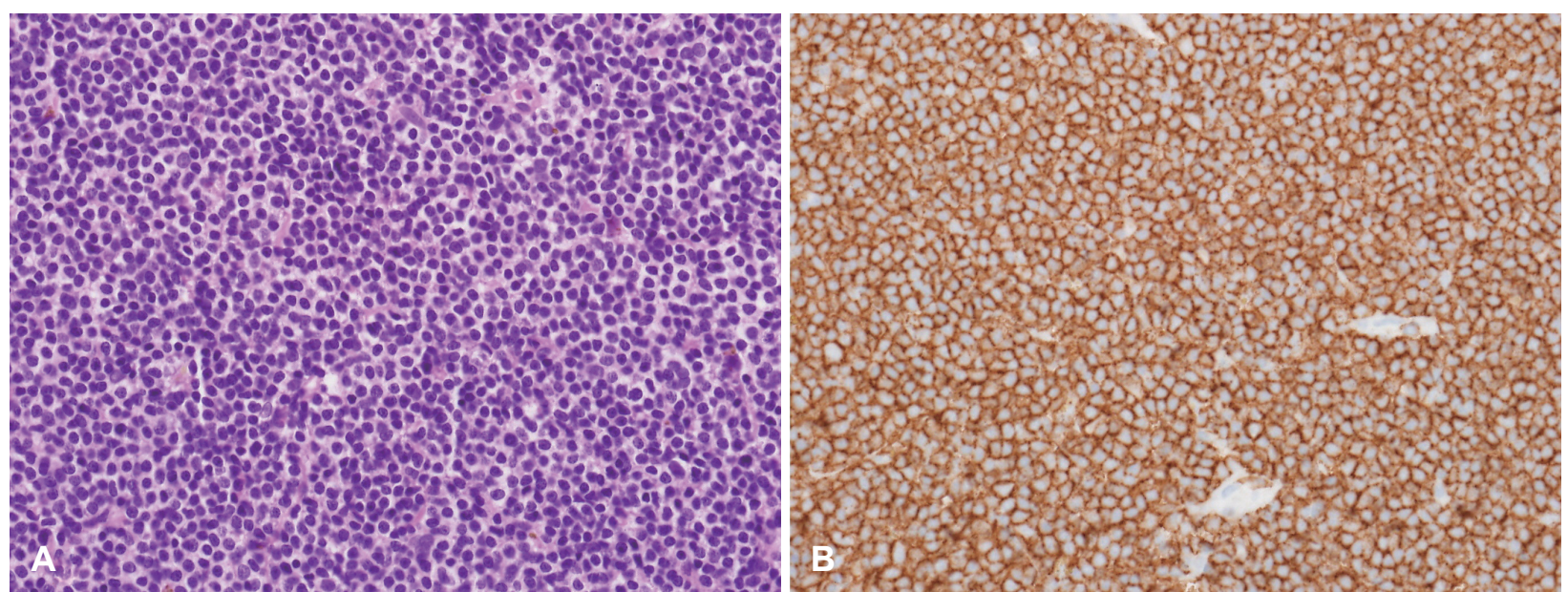

Fig. 5. Pathologic findings. Atypical plasma cells with abundant cytoplasm and hyperchromatic nuclei were shown (A; hematoxylin and eosin, $\times 400)$. Immunohistochemistric findings shown positive in CD20 stain (B; $\times 400)$.

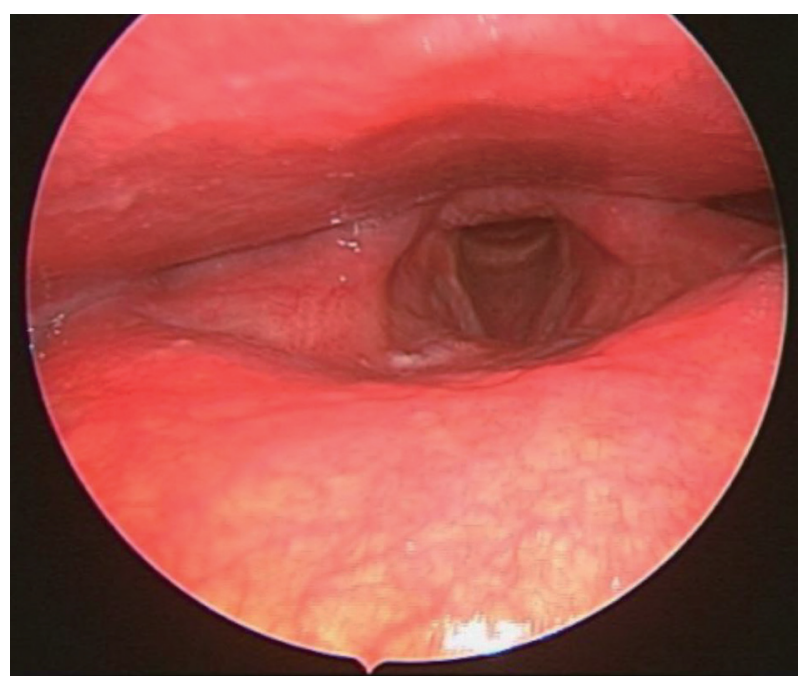

Fig. 6. Laryngoscope image that taken 1 month after local radiotherapy. Note clear margin of right false vocal cord.

증례에서 보이는 일반적인 육안적, 영상학적 특징과는 거리가 있었으나, 조직검사에서 주변 변연부로 침윤이 보이는 점막 연관 림프조직이 보였으며, 면역조직화학적 검사에서 $\mathrm{CD} 20$, $\mathrm{bcl}-2$ 염색에서 양성, CD5, cyclin D1 등의 염색에서 음성 소 견이 확인되어 MALT 림프종으로 진단하는데 합당하였다.

MALT 림프종의 병기를 결정할 때는 다른 호지킨성, 비호 지킨성 림프종과 같이 modified Ann Arbor 분류를 따른다. 대부분의 MALT 림프종은 위장관에 발생하므로 조기에는 H. pylori에 대한 제균 단일치료만으로 호전되는 것으로 알려 져 있다. ${ }^{10)}$ 반면에 본 증례와 같은 위장관 외에 발생한 MALT 림프종의 경우 확립되어 있는 치료원칙은 없으나, 병기에 따라 I, II단계의 경우 국소 방사선 치료를 일차적으로 사용할 수 있다. 특히 현재까지의 보고에 따르면 후두에 발생한 MALT 림프종의 경우 국소 방사선 치료에 잘 반응하는 것으로 알려
져 있다. ${ }^{11)} \mathrm{III}, \mathrm{IV}$ 단계의 경우 확립된 치료법은 없으나, 면역치 료, cyclophosphamide, doxorubicin, vincristine, and prednisone을 포함한 항암 화학 요법 등을 이용하여 치료할 수 있다.) 본 증례 환자의 경우 단일 부위, 림프절 외에 발생하였 으므로 modified Ann Arbor 분류에 따르면 IE 병기에 해당 되고 골수검사에서 골수침범이 보이지 않아, 국소 방사선 치 료를 시행하였으며 치료 후 완전히 관해 되었다.

후두에 발생하는 종괴는 대부분 상피세포 기원의 양성 혹 은 편평세포암종과 같은 악성 종괴이며, 이는 주로 진성대의 편평 상피로부터 발생하고, 가성대에 발생하는 종괴는 드물지 만 선양낭성암종 등의 침샘기원 종양이나 신경초종, 신경섬 유종 등의 신경기원 양성종양이 있다. 가성대 종괴는 후두 입 구를 막을 수 있고, 성대의 움직임을 감소시켜 음성변화와 호 흡곤란이 발생할 수 있다. ${ }^{12,13)}$ 음성변화를 주소로 내원한 본 증례의 경우, 후두의 종괴에 대해 초기에 시행한 조직검사 및 영상검사에서 아밀로이드증을 의심할 만한 영상학적 소견 외 에 특이 소견이 보이지 않아 일차적인 제거 후 경과 관찰하였 으나, 재발하게 되어 충분한 양의 조직검사를 통해 정확한 진 단을 내릴 수 있었다. 비록 후두에 발생하는 MALT 림프종은 매우 드물며, 본 증례의 경우 예후가 비교적 양호하였지만, 음 성변화를 주소로 내원한 환자에게서 가성대 종괴가 관찰될 경우 침샘기원 종양이나 신경기원 종양, 아밀로이드증 등의 양성 질환뿐만 아니라 편평세포암, 림프종의 악성 질환일 가 능성이 있으므로 정확한 진단이 필요하며 이를 위해 충분한 양의 조직을 확보하여 검사하는 것의 중요성을 다시 한번 일 깨워주는 증례라고 생각된다.

\section{Acknowledgments}

None. 


\section{Author Contribution}

Conceptualization: Min Woo Kim, Dong Sik Chang, Min Young Kwak. Data curation: Min Woo Kim, Dong Sik Chang, Jun Yong Choi. Formal analysis: Min Young Kwak. Resources: Min Woo Kim, Dong Sik Chang, Min Young Kwak. Writing — original draft: Min Woo Kim, Dong Sik Chang. Writing - review \& editing: all authors.

\section{ORCID}

Dong Sik Chang

https://orcid.org/0000-0003-1242-9894

\section{REFERENCES}

1) Burns H, Phillips N. Laryngeal amyloidosis. Curr Opin Otolaryngol Head Neck Surg 2019;27(6):467-74.

2) Bacon CM, Du MQ, Dogan A. Mucosa-associated lymphoid tissue (MALT) lymphoma: A practical guide for pathologists. J Clin Pathol 2007;60(4):361-72.

3) Zucca E, Bertoni F. The spectrum of MALT lymphoma at different sites: Biological and therapeutic relevance. Blood 2016;127(17): 2082-92.

4) Zucca E, Conconi A, Pedrinis E, Cortelazzo S, Motta T, Gospodarowicz MK, et al. Nongastric marginal zone B-cell lymphoma of mucosa-associated lymphoid tissue. Blood 2003; 101(7):2489-95.

5) Diebold J, Audouin J, Viry B, Ghandour C, Betti P, D’Ornano G. Primary lymphoplasmacytic lymphoma of the larynx: A rare localization of MALT-type lymphoma. Ann Otol Rhinol Laryngol 1990;99(7 Pt 1):577-80.

6) Hua J, Iwaki Y, Inoue M, Takiguchi Y, Ota Y, Hagihara M. Mucosaassociated lymphoid tissue lymphoma of the larynx. Rinsho Ketsueki 2014;55(3):340-4

7) Arndt S, Veelken H, Schmitt-Gräff A, Aschendorff A, Maier W, Richter B. Multifocal extranodal mucosa-associated lymphoid tissue lymphoma affecting the larynx. Ann Otol Rhinol Laryngol 2007; 116(4):257-61.

8) Wöhrer S, Troch M, Streubel B, Zwerina J, Skrabs C, Formanek M, et al. MALT lymphoma in patients with autoimmune diseases: A comparative analysis of characteristics and clinical course. Leukemia 2007;21(8):1812-8.

9) Harris NL, Isaacson PG. What are the criteria for distinguishing MALT from non-MALT lymphoma at extranodal sites? Am J Clin Pathol 1999;111(1 Suppl 1):S126-32.

10) Ahmad A, Govil Y, Frank BB. Gastric mucosa-associated lymphoid tissue lymphoma. Am J Gastroenterol 2003;98(5):975-86.

11) Cheng CJ, Chen PR, Liu MC, Kuo MS, Hsu YH. Primary malignant lymphoma of mucosa-associated lymphoid tissue of larynx. Otolaryngol Head Neck Surg 1999;121(5):661-2.

12) Ganly I, Patel SG, Coleman M, Ghossein R, Carlson D, Shah JP. Malignant minor salivary gland tumors of the larynx. Arch Otolaryngol Head Neck Surg 2006;132(7):767-70.

13) Thomas RL. Non-epithelial tumours of the larynx. J Laryngol Otol 1979;93(11):1131-41. 